\title{
Alginate Production from Alternative Carbon Sources and Use of Polymer Based Adsorbent in Heavy Metal Removal
}

\author{
Çiğdem Kıvılcımdan Moral and Merve Yıldız \\ Department of Environmental Engineering, Akdeniz University, 07058 Antalya, Turkey \\ Correspondence should be addressed to Çiğdem Kıvılcımdan Moral; cigdemkn@yahoo.com
}

Received 29 January 2016; Accepted 23 February 2016

Academic Editor: Bernabé Luis Rivas

Copyright (c) 2016 Ç. Kıvılcımdan Moral and M. Yıldız. This is an open access article distributed under the Creative Commons Attribution License, which permits unrestricted use, distribution, and reproduction in any medium, provided the original work is properly cited.

\begin{abstract}
Alginate is a biopolymer composed of mannuronic and guluronic acids. It is harvested from marine brown algae; however, alginate can also be synthesized by some bacterial species, namely, Azotobacter and Pseudomonas. Use of pure carbohydrate sources for bacterial alginate production increases its cost and limits the chance of the polymer in the industrial market. In order to reduce the cost of bacterial alginate production, molasses, maltose, and starch were utilized as alternative low cost carbon sources in this study. Results were promising in the case of molasses with the maximum $4.67 \mathrm{~g} / \mathrm{L}$ of alginate production. Alginates were rich in mannuronic acid during early fermentation independent of the carbon sources while the highest guluronic acid content was obtained as $68 \%$ in the case of maltose. The polymer was then combined with clinoptilolite, which is a natural zeolite, to remove copper from a synthetic wastewater. Alginate-clinoptilolite beads were efficiently adsorbed copper up to $131.6 \mathrm{mg} \mathrm{Cu}{ }^{2+} / \mathrm{g}^{2} \mathrm{dsorbent}$ at $\mathrm{pH} 4.5$ according to the Langmuir isotherm model.
\end{abstract}

\section{Introduction}

Alginate is a well-known biopolymer composed of mannuronic (M) and guluronic $(\mathrm{G})$ acid monomers. It is still harvested from marine brown algae although some species of bacteria such as Azotobacter and Pseudomonas can produce alginate. Properties of alginate highly depend on the type of algae, climate conditions, environmental pollution, and so forth [1]. On the other hand, characteristics of bacterial alginate can be manipulated by changing, for example, bacterial strains and experimental conditions. However, bacterial alginate is out of this industrial market because of its higher production cost compared to algal alginate. One of the main parameters influencing the price of bacterial alginate is the carbon source used for the production. As it is known that bacterial alginate production was investigated for years by using usually glucose and sucrose since they are simple sugars, the bacteria can easily assimilate them [2-4]. Either a waste stream (generally food processing wastewaters contain some sugars such as brewery, fruit processing, and cheese whey) or a cheaper carbon source might be alternatives in order to decrease the cost of biopolymer production.
Molasses, a byproduct of sugar manufacturing, can be an example to a cheaper source. Molasses contains mostly sugars like sucrose, glucose, and fructose comprising up to 50\% [5]. It was investigated as a carbon source for polyhydroxyalkanoates [6], polyhydroxybutyrate (PHB) [7], cellulose [8], and xanthan [9] production and biopolymers having different sugar contents reported [10-13]. On the other hand, alginate production from molasses was comparably rare. Only two works reported EPS production alginate in nature [14, 15]. Maltose is the main sugar in brewery wastewater since, during the process, malt is converted to sugar, maltose, some of which is also wasted by water [16]. Very limited number of studies utilized maltose or brewery wastewater as carbon source. In one study, maltose was used to produce PHB [7] while in the other study it was used to produce a bioflocculant [17]. In addition, only one study used brewery wastewater for biopolymer production and then the polymer was used for removal of some reactive soluble dyes [18]. Similarly, starch is found in some wastewater such as effluents that come from facilities utilized potatoes as a raw material [19]. Starch was also used to decrease biopolymer production cost such as 
PHB [20-24], xanthan [25], gellan [26], cellulose [27], and bioflocculants [28].

Alginate has lots of applications in different industries due to its gelling ability and viscous character. In wastewater treatment, it was used to remove various pollutants such as heavy metals, dyes, and phenolic compounds [29-32]. Copper is one of the heavy metals threatening our water resources. It is quite toxic at high concentrations and tends to accumulate fatty tissues of livings. Therefore, it should be removed from wastewaters before being discharged. Due to gelling ability of alginate, alginate beads, formed by adding mostly calcium, were used for heavy metal removal. Recent studies were particularly focused on improvement of alginate beads by adding some materials capable of capturing heavy metals such as clay, bentonite, and activated carbon [30, 33, 34]. In this study, a natural zeolite, clinoptilolite, was used to increase copper removal capacity of alginate beads. Clinoptilolites can selectively remove heavy metals [35-37] and they are also preferred due to their cost efficiency and abundancy in our country. With all things considered, this study was aimed at addressing whether the proposed carbon sources, namely, molasses, maltose, and starch, were good candidates for alginate production or not. Then, the polymer was combined with clinoptilolite to obtain alginate-clinoptilolite (A-C) beads in order to investigate efficiency of copper removal.

\section{Materials and Methods}

2.1. Microorganism and Cultivation Medium. Azotobacter vinelandii ATCC $^{\circledR} 9046$ was stored at $-20^{\circ} \mathrm{C}$ in $20 \%$ of glycerol solution. For alginate production, a modified Burk's medium was used with changing related sugars. It contains sugar beet molasses/maltose/starch $(20 \mathrm{~g} / \mathrm{L})$, yeast extract (Merck) $(3 \mathrm{~g} / \mathrm{L}), \mathrm{K}_{2} \mathrm{HPO}_{4}(0.66 \mathrm{~g} / \mathrm{L}), \mathrm{KH}_{2} \mathrm{PO}_{4}(0.16 \mathrm{~g} / \mathrm{L})$, MOPS (1.42 g/L), $\mathrm{CaSO}_{4} \quad(0.05 \mathrm{~g} / \mathrm{L}), \quad \mathrm{NaCl} \quad(0.2 \mathrm{~g} / \mathrm{L})$, $\mathrm{MgSO}_{4} \cdot 7 \mathrm{H}_{2} \mathrm{O}(0.2 \mathrm{~g} / \mathrm{L}), \mathrm{Na}_{2} \mathrm{MoO}_{4} \cdot 2 \mathrm{H}_{2} \mathrm{O}(0.0029 \mathrm{~g} / \mathrm{L})$, and $\mathrm{FeSO}_{4} \cdot 7 \mathrm{H}_{2} \mathrm{O}(0.027 \mathrm{~g} / \mathrm{L})$. The salts, $\mathrm{K}_{2} \mathrm{HPO}_{4}, \mathrm{KH}_{2} \mathrm{PO}_{4}, \mathrm{NaCl}$, and $\mathrm{MgSO}_{4} \cdot 7 \mathrm{H}_{2} \mathrm{O}$, were sterilized together by autoclaving at $121^{\circ} \mathrm{C}$ for $30 \mathrm{~min}$. After that, sugars and $\mathrm{CaSO}_{4}$ were sterilized separately and added into these salts. Finally, $\mathrm{FeSO}_{4} \cdot 7 \mathrm{H}_{2} \mathrm{O}$ and $\mathrm{Na}_{2} \mathrm{MoO}_{4} \cdot 2 \mathrm{H}_{2} \mathrm{O}$ were separately filtered for sterilization through $0.22 \mu \mathrm{m}$ filter (Millipore Millex GS) and added to the mixture. $\mathrm{pH}$ was adjusted to 7.2 by the addition of $\mathrm{NaOH}$ or $\mathrm{HCl}(0.1$ or $1 \mathrm{M})$. Before the experiments, the bacterium was activated by conducting a preculture. For the preparation of preculture, $1 \mathrm{~mL}$ of the stock culture was added to $250 \mathrm{~mL}$ Erlenmeyer flask containing $50 \mathrm{~mL}$ modified Burk's medium. This culture was grown at $30^{\circ} \mathrm{C}$ temperature by shaking at $200 \mathrm{rpm}$ for 48 hours and used to inoculate a fresh medium.

2.2. Alginate Production. Three different carbon sources, molasses, maltose, and starch, were proposed as alternative carbon source for alginate production. First, alginate production potentials of these carbon sources were investigated by conducting flask experiments. Each flask containing $50 \mathrm{~mL}$ of medium $(250 \mathrm{~mL})$ was inoculated at $4 \%(\mathrm{v} / \mathrm{v})$ and incubated at $30^{\circ} \mathrm{C}$ and $250 \mathrm{rpm}$ during 72 hours. Glucose and sucrose were also applied as references to conventional carbon sources. All experiments were performed in triplicate. Then, both molasses and maltose were selected to elucidate the kinetics of alginate production. For this purpose, alginate and bacterial mass, residual sugar concentration, and monomer distribution of the polymer were followed by taking a flask at each predetermined time interval under the same conditions mentioned above. Similarly, all experiments were performed in triplicate and the results were given as averages.

\subsection{Analytical Methods}

2.3.1. Bacteria and Alginate Determination. $25 \mathrm{~mL}$ of culture broth was mixed with $2.5 \mathrm{~mL}$ of $\mathrm{Na}_{4}$ EDTA $(0.1 \mathrm{M})$ and $1.5 \%$ $(\mathrm{w} / \mathrm{v}) \mathrm{NaCl}$ for $10 \mathrm{~min}$. Too viscous samples were diluted and then centrifuged at $4000 \mathrm{rpm}$ for $45 \mathrm{~min}$. A $0.45 \mu \mathrm{m}$ membrane filter was used to filter the supernatant and it was deacetylated after addition of $\mathrm{NaOH}(0.1 \mathrm{M})$ by shaking for 1 hour. After that, the polymer was precipitated as alginic acid by decreasing the $\mathrm{pH}$ to around 2 and incubated for $30 \mathrm{~min}$ at $4^{\circ} \mathrm{C}$. An additional washing with $0.1 \mathrm{~N}$ cold $\mathrm{HCl}$ solution was applied after centrifugation at $4000 \mathrm{rpm}$ for $10 \mathrm{~min}$. Then, alginic acid pellets were dissolved in small amount of distilled water and precipitated by ethanol $(1: 1)$ with the addition of $\mathrm{NaCl}(0.2 \% \mathrm{w} / \mathrm{v})$. Extracted polymer was washed three times with ethanol (70\%) and then once with pure ethanol and then with ether. Finally, it was dried and weighed [38]. For bacterial mass determination, the precipitate from the first centrifugation was resuspended in distilled water and filtered through $0.45 \mu \mathrm{m}$ membrane filter. After that, it was dried at $105^{\circ} \mathrm{C}$ for 1 hour, cooled, and weighed.

2.3.2. Carbohydrate Analysis. Sugars, other than glucose, were degraded by heating at $90^{\circ} \mathrm{C}$ for 5 min with the addition of concentrated $\mathrm{HCl}$. Then, the solution was neutralized by $\mathrm{NaOH}(5 \mathrm{~N})$. After that, DNS method was applied for the measurements of sugar concentrations [39].

2.3.3. Monomer Distribution. ${ }^{1} \mathrm{H}-\mathrm{NMR}$ spectroscopy was utilized for the determination of monomer distribution of alginates produced during experiments. To obtain good signals, alginate samples were required to be degraded by using partial acid hydrolysis before any measurements. Alginate $(0.1 \mathrm{~g})$ was added into $100 \mathrm{~mL}$ of distilled water. $\mathrm{pH}$ was adjusted to 5.6 and heated at $100^{\circ} \mathrm{C}$ for 1 hour. After that, $\mathrm{pH}$ was reduced to 3.8 and heated once again at $100^{\circ} \mathrm{C}$ for $30 \mathrm{~min}$. Then, the solution was neutralized and freeze-dried. For instrumental analysis, $10 \mathrm{mg}$ of alginate was added into $0.5 \mathrm{~mL}$ of $\mathrm{D}_{2} \mathrm{O}$ and $10 \mu \mathrm{L}$ of $0.3 \mathrm{M}$ EDTA was added to eliminate interaction of divalent cations with alginate. ASTM F 2259-03 method was used as a guide and the ${ }^{1} \mathrm{H}-\mathrm{NMR}$ signals of alginate monomers were detected [40].

2.4. Preparation of A-C Beads. Alginate synthesized from maltose was used for the preparation of A-C beads due to its higher guluronic acid content. Clinoptilolite was first ground and then sieved into different fractions in the range of 100 and $500 \mu \mathrm{m}$. The one with the lowest particle size, $<100 \mu \mathrm{m}$, was selected during experiments since it was thought that the lower the particle size, the higher the surface area available for heavy metal removal. After that, to increase heavy metal 
uptake capacity of clinoptilolite, $10 \mathrm{~g}$ of clinoptilolite was shaken with $250 \mathrm{~mL} \mathrm{NaCl}$ solution $(2 \mathrm{M})$ at $150 \mathrm{rpm}$ during 24 hours. At the end, clinoptilolite was washed with distilled water, dried at $100^{\circ} \mathrm{C}$ during 24 hours, and stored in a desiccator. The ratio for the preparation of $\mathrm{A}-\mathrm{C}$ beads was selected as $1: 1$. First $2 \%$ of alginate solution was prepared and equal amount of clinoptilolite was added into the solution. Then, the mixture was added dropwise into $50 \mathrm{mM} \mathrm{CaCl}$ solution under constant stirring. Beads were allowed to stand overnight in order to harden. Finally, they were filtered and washed at least three times with distilled water.

2.5. Heavy Metal Removal Procedure. First, $100 \mathrm{mg}$ of alginate and $\mathrm{A}-\mathrm{C}$ beads were incubated in $100 \mathrm{mg} / \mathrm{L}$ of $\mathrm{Cu}^{2+}$ solution (100 mL within $250 \mathrm{~mL}$ flask) at $\mathrm{pH} 4.5,200 \mathrm{rpm}$, and $30^{\circ} \mathrm{C}$ during 24 hours to compare effectiveness in copper removal. Initial and final metal concentrations were analyzed by Inductively Coupled Plasma Mass Spectroscopy (ICP-MS). Then, $100 \mathrm{mg}$ of A-C beads was subjected to different copper concentrations $(50,100,150,200$, and $250 \mathrm{mg} / \mathrm{L})$ at $\mathrm{pH} 4.5$, $200 \mathrm{rpm}$, and $30^{\circ} \mathrm{C}$ during 24 hours. Initial and final metal concentrations were analyzed by ICP-MS. All experiments were conducted in triplicate and the results were given as averages.

2.6. Evaluation of Copper Adsorption onto A-C Beads. Adsorption isotherms were used to evaluate distribution of adsorbed matter between solid and liquid phases. The amount of copper taken by A-C beads can be calculated as follows:

$$
q_{e}=\frac{C_{0}-C_{e}}{m}
$$

where $q_{e}(\mathrm{mg} / \mathrm{g})$ is the amount of the metal adsorbed per unit mass of adsorbent, $C_{o}$ and $C_{e}(\mathrm{mg} / \mathrm{L})$ are the initial and equilibrium concentration of the metal in the solution, and $m$ $(\mathrm{g} / \mathrm{L})$ is the amount of adsorbent added into the solution. The Freundlich and Langmuir isotherms were evaluated whether they were suitable or not to simulate the experimental data. The Freundlich isotherm can be expressed as follows:

$$
q_{e}=K_{F} \times C_{e}^{1 / n}
$$

where $K_{F}$ and $n$ are constants which indicate adsorption capacity and intensity, respectively. On the other hand, the Langmuir isotherm can be expressed as follows:

$$
q_{e}=\frac{q_{\max } \times K \times C_{e}}{1+K \times C_{e}}
$$

where $q_{\max }(\mathrm{mg} / \mathrm{g})$ is the maximum adsorption capacity and $K(\mathrm{~L} / \mathrm{mg})$ is the Langmuir affinity constant between the adsorbent and the adsorbate. Both isotherms were applied in their linear forms.

\section{Results and Discussion}

3.1. Evaluation of Alginate Production from Different Carbohydrates. As it was mentioned earlier, generally simple and pure carbohydrates were preferred for alginate production.

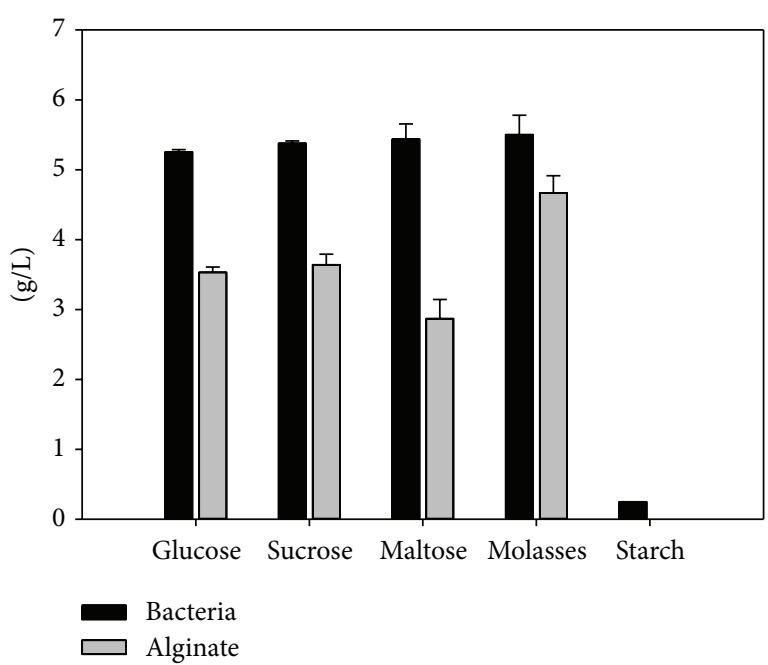

FIGURE 1: Variations of alginate production at different carbon sources.

However, it is very important to reduce the cost of bacterial alginates so that they can be alternative to algal sources. For this purpose, three different carbon sources were selected to investigate alginate production together with properties of the polymer, particularly monomer distribution. These sources are, namely, maltose, molasses, and starch. First, alginate production and bacterial mass were obtained after 72 hours of incubation at $30^{\circ} \mathrm{C}$ and $250 \mathrm{rpm}$ by Azotobacter vinelandii ATCC $^{\circledR}$ 9046. Glucose and sucrose were also subjected to alginate production for comparison.

As it is seen from Figure 1, in general, bacterial mass was similar for all sugars tested except starch. It was changed between 5.25 and $5.5 \mathrm{~g} / \mathrm{L}$ after 72 hours. One can say that bacteria are able to utilize maltose and molasses easily similar to glucose and sucrose. Accordingly, sugar utilization yields for bacterial production were also close being around $0.3 \mathrm{~g}$ bacteria/g sugar (Figure 2 and some of the data not shown). It is expected that, in fact, maltose is a disaccharide composed of two glucose units and as it was stated before, sugar content of molasses is mostly glucose, fructose, and sucrose. Different from them, almost no bacterial growth was observed when starch was used as a sole carbon source within 72 hours. The reason might be polymeric nature of starch which is composed of glucose monomers. On the other hand, alginate production was observed around $3.5 \mathrm{~g} / \mathrm{L}$ in the case of glucose and sucrose which corresponded to a yield of around $0.67 \mathrm{~g}$ alginate/g bacteria. It was found comparably lower when maltose was replaced with these sugars being about $2.87 \mathrm{~g} / \mathrm{L}$. This value is $20 \%$ lower than alginate concentration obtained by using sucrose and its yield based on bacterial mass is about $0.527 \mathrm{~g}$ alginate $/ \mathrm{g}$ bacteria. Synthesis of alginate appeared to be stimulated by using molasses as a sole carbon source. It was increased to $4.67 \mathrm{~g} / \mathrm{L}$ ( $0.849 \mathrm{~g}$ alginate $/ \mathrm{g}$ bacteria) after 72 hours of incubation at $250 \mathrm{rpm}$ and $30^{\circ} \mathrm{C}$. It is reported that molasses contains some minerals, vitamins, and protein sources together with sugars which might improve biopolymer synthesis in Azotobacter vinelandii [11]. These values were in the range reported in the literature using wild strains 


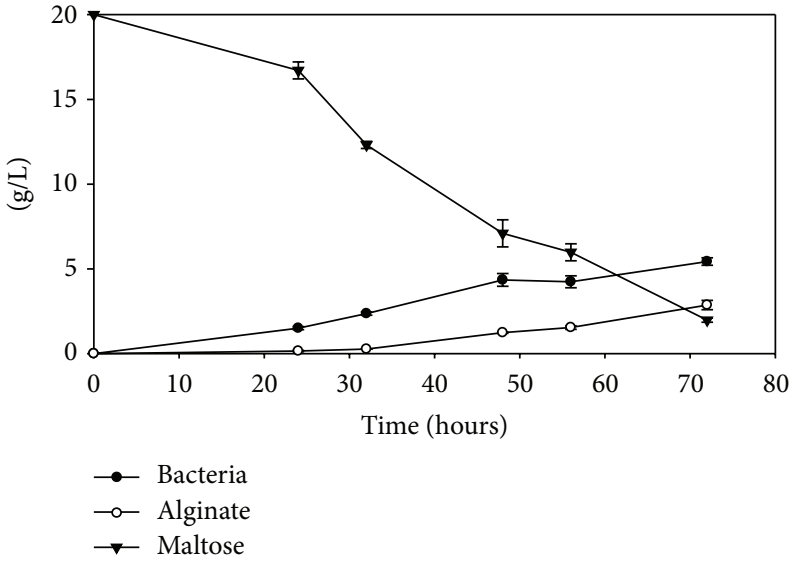

(a)

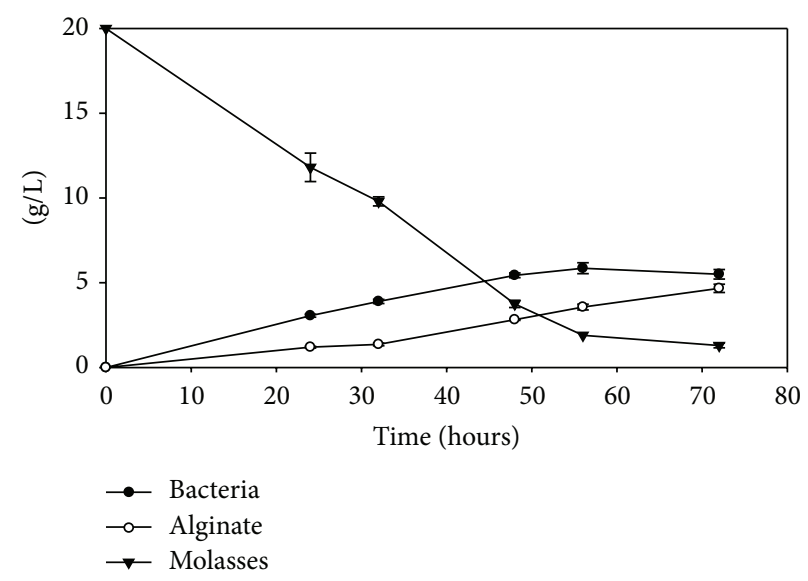

(b)

FIGURE 2: Changes in bacterial mass and alginate production from maltose and molasses.

$[3,41,42]$. In addition, there was no alginate production in the case of starch as expected from bacterial growth. Actually, some works utilized starch for biopolymer production after enzymatic degradation [27], acid treatment [43], or bacterial hydrolyses [25]. Pretreatment of starch might be the solution supplying easily degradable sugar to the bacteria for alginate production. However, this also means that degradation of starch requires additional steps in polymer production and might produce some additional wastes.

Since only the amounts of alginate from maltose and molasses were observed to be comparable with glucose and sucrose, the experiments were continued to examine how alginate production was changing with time using these carbon sources (Figure 2). As it is seen in Figure 2(a), bacterial growth was particularly faster within the first 48 hours in the case of maltose and then it slowed down. The highest bacterial mass was obtained after 72 hours as $5.44 \mathrm{~g} / \mathrm{L}$. Alginate production followed almost the same trend with bacterial growth which means most of the alginate was produced by growing bacteria. This might indicate that oxygen level in flaks is limited so that bacteria are able to produce alginate during growth. There were some previous results that alginate production was delayed until late exponential phase $[4,42]$. It is probably due to higher oxygen level observed at the beginning of incubation as a result of low bacterial mass according to the mixing regime. Under high oxygenated conditions, bacteria may use the carbon source to increase respiration rate other than alginate production in order to protect their sensitive enzymes from oxygen. On the other hand, the maximum alginate concentration was obtained as $2.87 \mathrm{~g} / \mathrm{L}$ when maltose was used. Compatible with bacterial growth and alginate production, maltose utilization rate increased after 24 hours and then continued until the end of the experiment. At this point, $90 \%$ of maltose was used; that is, only about $2 \mathrm{~g} / \mathrm{L}$ of maltose remained in the medium. As it is easily seen from Figure 2(b), molasses was utilized faster compared to maltose. About half of it was already used at 32 hours and this trend was consistent until 56 hours. Similar to maltose utilization, almost all of molasses were exhausted after 72 hours. Faster use of molasses also resulted in better bacterial production and alginate synthesis compared to maltose. Particularly during early times of incubation, bacteria concentration was higher in the case molasses. The highest bacterial mass was achieved at 56 hours as $5.86 \mathrm{~g} / \mathrm{L}$ although bacterial growth rate was somewhat reduced after 48 hours. Furthermore, alginate concentration was increased until 72 hours, at which it was at maximum, up to $4.67 \mathrm{~g} / \mathrm{L}$. Accordingly, alginate yield based on carbon source utilization was increased from 0.159 to $0.249 \mathrm{~g}$ alginate/g sugar utilized when maltose was replaced with molasses. An alginate based exopolysaccharide was also obtained being around $7.5 \mathrm{~g} / \mathrm{L}$ at 2\% of molasses by using local Azotobacter isolates [15].

Alginate is an industrial polymer used as thickener, stabilizer, and binding and gelling agent in food, cosmetic, pharmaceutical/medical, and material industries [1]. Among these useful properties, its gelling ability mainly depends on distribution of the two monomers in the polymer chain. Alginate is synthesized as mannuronic acid first and then it is epimerized into guluronic acid monomer. Mainly extracellular epimerases designated as Alg E1-Alg E7 and also Alg $\mathrm{G}$ are responsible for epimerization in Azotobacter vinelandii [44]. As expected, at the very beginning of incubation period, alginate was rich in mannuronic acids in the cases of both maltose and molasses (Figure 3). M-blocks content was quickly decreased from 45 to $19 \%$ between 24 and 32 hours in the case of maltose while MG and particularly Gblocks were increasing. Then, M-blocks content showed some little variations throughout the incubation period. After 48 hours, MG-blocks content was also started to decrease from 48 to $26 \%$ and G-blocks were found dominant in alginate chain at 72 hours as $55 \%$ in the case of maltose. Similarly, amount of M-blocks was reduced throughout the experiment in the case of molasses. It seems that there is slower reduction in M-blocks content accompanied with lower epimerization rate, particularly with epimerization into G-blocks, compared to the trend observed in the case of maltose. Thus, alginate 


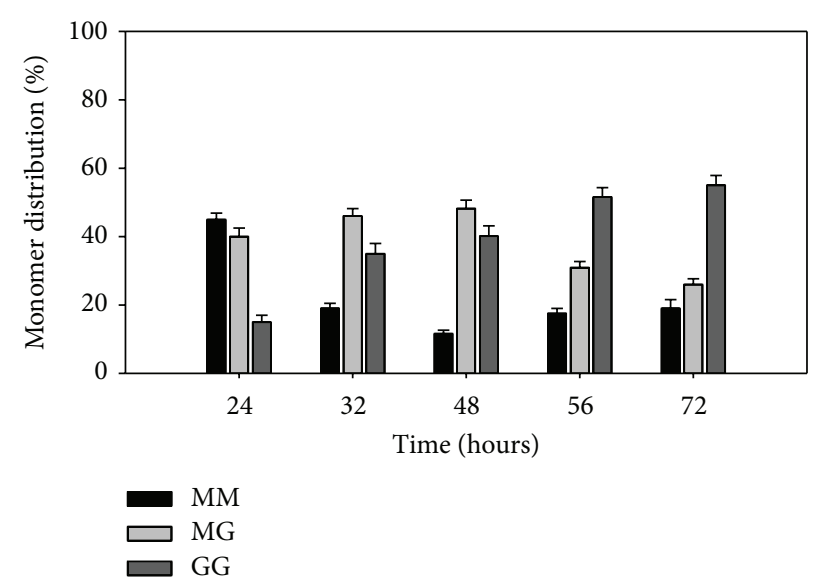

(a)

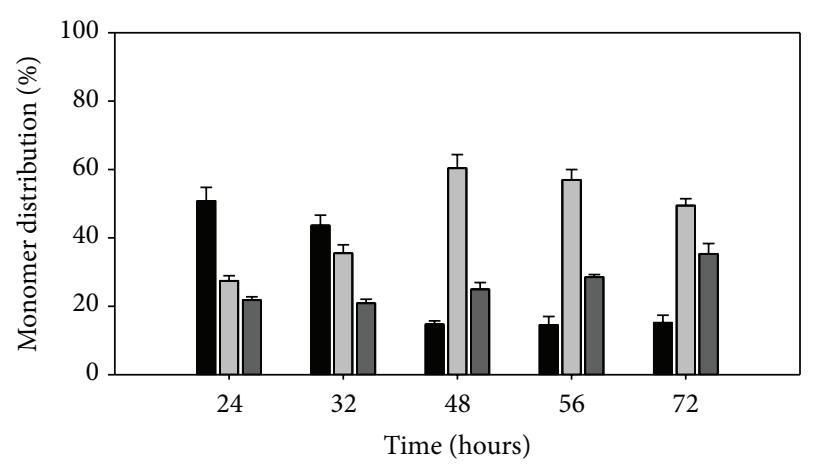

MM
MG
GG

FIGURE 3: Variations in monomer distribution of alginate by maltose and molasses.

was dominant of MG-blocks after 48 hours with the highest level of $60 \%$ in the case of molasses. Also, even at 72 hours of incubation, there were still about $50 \%$ of MG-blocks. Therefore, the maximum G-blocks level could be achieved as 35\% at the end of experiment when molasses was used as the carbon source. There is only one work that reported monomer distribution of alginate obtained by Azotobacter vinelandii at $60 \mathrm{~g} / \mathrm{L}$ of molasses. Comparably higher guluronic acid containing polysaccharide (mainly composed of alginate) $82 \%$ could be synthesized; however, accurate composition of alginate in terms of dimeric composition was not reported [14].

3.2. Use of Alginate-Zeolite Based Adsorbent for Copper Removal. Adsorption is an alternative method for heavy metal removal which is cheap, easy to apply, and effective when it is compared to conventional methods such as chemical precipitation, ion exchange, and membrane technologies. In this study, alginate was applied as an adsorbent in the form of calcium alginate beads for the removal of copper. In order to improve heavy metal removal potential of these beads, clinoptilolite was used since it can selectively exchange heavy metals from wastewaters. Furthermore, there are 500 million tons and 20 million tons of clinoptilolite present at BalıkesirBigadiç and Manisa-Gördes, respectively, in Turkey.

As mentioned above, the practical aim for this part of the study was to prepare a new alginate bead combination in order to have better copper removal efficiency. First, alginate beads were compared with A-C beads for copper removal at $100 \pm 5.4 \mathrm{mg} / \mathrm{L}$ of initial metal concentration at $\mathrm{pH} 4.5$. Copper removal efficiency was found higher in the case of AC beads. About $64 \%$ of copper was adsorbed by alginate beads while A-C beads reached up to $83 \%$ copper removal (data not shown). That is, these beads resulted in almost $20 \%$ higher copper removal under the same environmental conditions. Although diffusional limitations might limit heavy metal removal in A-C beads, increase in available sites suitable for ion exchange at clinoptilolite surface may result in higher copper removal from the solution.

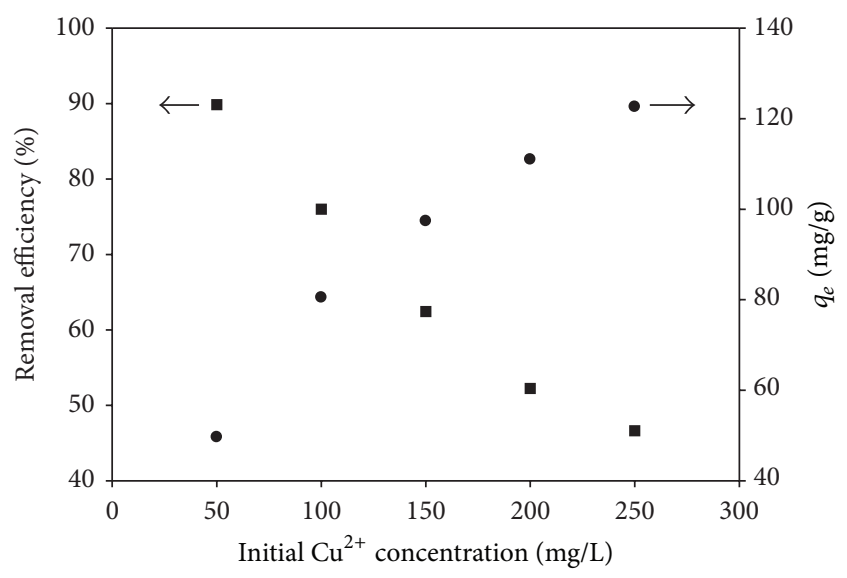

FIgure 4: Copper uptake by A-C beads at different initial copper concentrations.

Figure 4 shows the results obtained from copper removal by $\mathrm{A}-\mathrm{C}$ beads at different initial copper concentrations at $\mathrm{pH}$ 4.5 and $30^{\circ} \mathrm{C}$ after 24 hours of incubation. Maximum removal of copper was obtained at the lowest metal concentration, $50 \pm 5.2 \mathrm{mg} / \mathrm{L}$ of $\mathrm{Cu}^{2+}$. Only $5.6 \mathrm{mg} / \mathrm{L}$ of $\mathrm{Cu}^{2+}$ was left behind in the solution which corresponded to about $90 \%$ of copper removal. This may be explained by the higher amount of active sites available for adsorption at low concentrations of copper. As the initial copper concentration was increased, the heavy metal removal efficiency was decreased gradually. The minimum value was calculated as $47 \%$ at $250 \pm 13 \mathrm{mg} / \mathrm{L}$ of initial $\mathrm{Cu}^{2+}$ concentration. Opposite to the removal efficiency, adsorption capacity per unit mass of adsorbent was found positively proportional with initial copper ion concentration. The highest copper adsorption was obtained as $122.6 \mathrm{mg} \mathrm{Cu}{ }^{2+} / \mathrm{g} \mathrm{A}-\mathrm{C}$ beads at $250 \pm 13 \mathrm{mg} / \mathrm{L}$ of initial $\mathrm{Cu}^{2+}$ concentration. This is probably because of increased contact opportunities between A-C beads and copper at higher concentration levels. Also, increase in initial copper concentration might help as a driving force to overcome the 
TABLE 1: Comparison of the maximum copper adsorption capacities.

\begin{tabular}{|c|c|c|c|}
\hline Adsorbent & $q_{\mathrm{Max}}(\mathrm{mg} / \mathrm{g})$ & $K(\mathrm{~L} / \mathrm{mg})$ & Reference \\
\hline $\mathrm{Cu}$-Polyvinyl alcohol-sodium alginate & 94.34 & 0.13 & {$[45]$} \\
\hline Activated carbon-alginate beads & 143 & 0.0347 & {$[46]$} \\
\hline Calcium alginate-graphene oxide & 60.2 & 0.0129 & {$[47]$} \\
\hline Calcium alginate and hydrogen alginate & 107 and 189 & 0.16 and 0.10 & {$[48]$} \\
\hline Na-montmorillonite-alginate beads & 60.6 & 0.063 & [29] \\
\hline Carbon nanotube-calcium alginate & 84.88 & 0.78 & [49] \\
\hline Calcium alginate magnetic sorbent & 60.24 & 1.43 & {$[50]$} \\
\hline Alginate immobilized bentonite clay & 131.58 & - & {$[33]$} \\
\hline Calcium alginate-zeolite composite & 121.1 & - & {$[51]$} \\
\hline Alginate-clinoptilolite beads & 131.6 & 0.067 & This study \\
\hline
\end{tabular}

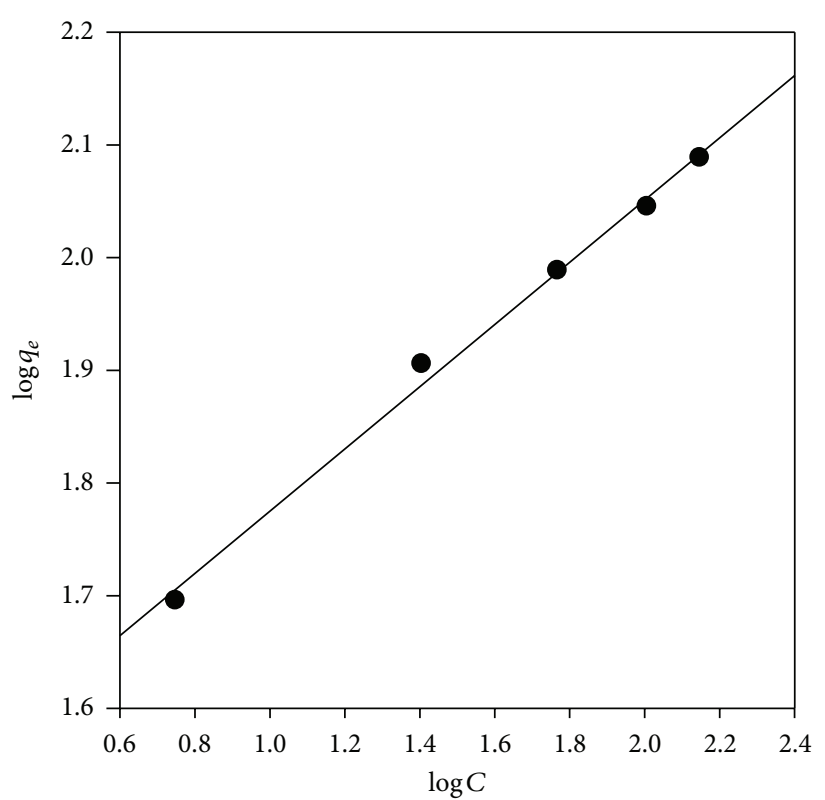

(a)

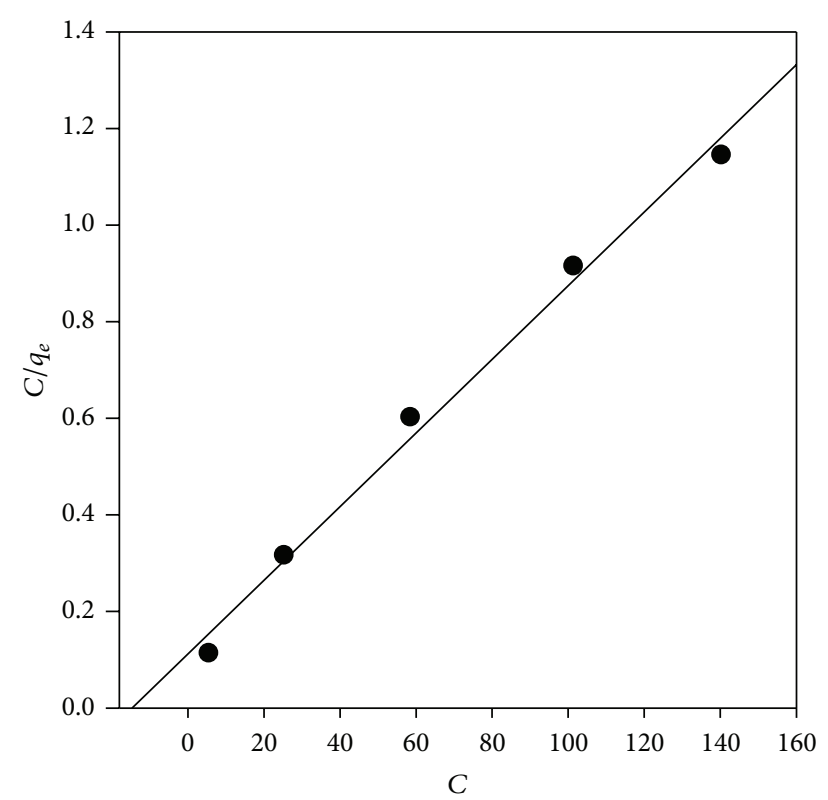

(b)

FIGURE 5: Adsorption isotherms: (a) Freundlich and (b) Langmuir.

mass transfer resistance of the metal from liquid phase to solid phase.

Evaluation of adsorption processes was performed by constructing adsorption isotherms since they are significant to design adsorption systems. They show the distribution of adsorbate between solid and liquid phase after adsorption equilibrium is achieved. For this purpose, wellknown models such as Freundlich and Langmuir isotherms were selected to correlate experimental equilibrium data (Figure 5). As it is shown in the figure, copper adsorption onto A-C beads is fitted to both isotherms. Correlation coefficient, $R^{2}$, values are similar and they are 0.9945 and 0.9917 for Freundlich and Langmuir isotherms, respectively. Therefore, these adsorption models seem to be suitable to evaluate copper adsorption onto A-C beads. Then, the data were used to calculate Freundlich and Langmuir isotherm constants. The Freundlich model depends on heterogeneous surface which means that binding sites are not equivalent and independent. The Freundlich isotherm constants $\left(K_{F}\right.$ and $n$ ) give idea about adsorption capacity and intensity. Value of $n$ higher than unity (which is 3.62 in this study) means favorable adsorption. The Langmuir model is generally used as single-component adsorption. As it is shown in Table 1, equilibrium binding capacity of the beads is calculated as $131.6 \mathrm{mg} \mathrm{Cu}{ }^{2+} / \mathrm{g} \mathrm{A}-\mathrm{C}$ beads for the Langmuir model. This value is considerably better compared to the current literature (Table 1). The good adsorption capacity of A-C beads can be mainly attributed to ion exchange with calcium ion on carboxylic sites in the polymer chain and sodium ion in the zeolite. Also, higher selectivity of guluronic acid blocks on heavy metal ions may play a role since affinity of alginate for copper is higher compared to calcium ion. Furthermore, in Langmuir isotherm model, $K$ represents the affinity of the adsorbate, $\mathrm{Cu}^{2+}$ ions, for the binding site of the adsorbent, $\mathrm{A}$ $\mathrm{C}$ beads. That is, higher $K$ values mean that the metal ion can be easily adsorbed at the available sites on the adsorbent. It 
can be seen from Table 1 that $K$ values are changing depending on the type of the adsorbents. A-C beads seem to have moderate affinity for copper ions since $K$ value is approximately in the middle of the reported range (0.0129-1.43), which is 0.067 .

\section{Conclusions}

Bacterial alginate production is required to be cost-effective to compete with algal alginate. Molasses resulted in high alginate yield and maltose appeared to be promising. In terms of monomer distribution, guluronic acid content was found to be higher when maltose was utilized; however, this might not be high enough to prepare very hard gels. Thus, application potential of the polymer depends on the intended use. In this study, A-C beads were performed and found to be effective in copper removal. Therefore, alginate produced from cheaper sources and combined with a local material to achieve heavy metal removal would be a valuable asset.

\section{Competing Interests}

The authors declare that they have no competing interests.

\section{Acknowledgments}

This study was funded by Akdeniz University Research Fund (no. 2013.01.0102.011).

\section{References}

[1] I. D. Hay, Z. U. Rehman, A. Ghafoor, and B. H. A. Rehm, "Bacterial biosynthesis of alginates," Journal of Chemical Technology and Biotechnology, vol. 85, no. 6, pp. 752-759, 2010.

[2] C. Peña, M. Millán, and E. Galindo, "Production of alginate by Azotobacter vinelandii in a stirred fermentor simulating the evolution of power input observed in shake flasks," Process Biochemistry, vol. 43, no. 7, pp. 775-778, 2008.

[3] W. Sabra, A.-P. Zeng, H. Lunsdorf, and W.-D. Deckwer, "Effect of oxygen on formation and structure of Azotobacter vinelandii alginate and its role in protecting nitrogenase," Applied and Environmental Microbiology, vol. 66, no. 9, pp. 4037-4044, 2000.

[4] E. Parente, M. A. Crudele, A. Ricciardi, M. Mancinià, and F. Clementi, "Effect of ammonium sulphate concentration and agitation speed on the kinetics of alginate production by Azotobacter vinelandii DSM576 in batch fermentation," Journal of Industrial Microbiology and Biotechnology, vol. 25, no. 5, pp. 242-248, 2000.

[5] D. Teclu, G. Tivchev, M. Laing, and M. Wallis, "Determination of the elemental composition of molasses and its suitability as carbon source for growth of sulphate-reducing bacteria," Journal of Hazardous Materials, vol. 161, no. 2-3, pp. 1157-1165, 2009.

[6] F. Pardelha, M. G. E. Albuquerque, M. A. M. Reis, J. M. L. Dias, and R. Oliveira, "Flux balance analysis of mixed microbial cultures: application to the production of polyhydroxyalkanoates from complex mixtures of volatile fatty acids," Journal of Biotechnology, vol. 162, no. 2-3, pp. 336-345, 2012.

[7] C. Arunachalam and R. Rajasekaran, "Studies on the productivity of poly- $\beta$-hydroxybutyrate by Alcaligenes eutrophus and Rhizobium meliloti using waste substrate," Journal of Pure and Applied Microbiology, vol. 3, no. 2, pp. 685-689, 2009.
[8] J.-H. Lin, W.-P. Sung, T.-Y. Chen, Y.-J. Lin, and J.-C. Kuo, "Applying the Taguchi method in improving the production of bacterial cellulose," Journal of Biobased Materials and Bioenergy, vol. 6, no. 6, pp. 610-613, 2012.

[9] S. Kalogiannis, G. Iakovidou, M. Liakopoulou-Kyriakides, D. A. Kyriakidis, and G. N. Skaracis, "Optimization of xanthan gum production by Xanthomonas campestris grown in molasses," Process Biochemistry, vol. 39, no. 2, pp. 249-256, 2003.

[10] Muhammadi and M. Afzal, "Optimization of water absorbing exopolysaccharide production on local cheap substrates by Bacillus strain CMG1403 using one variable at a time approach," Journal of Microbiology, vol. 52, no. 1, pp. 44-52, 2014.

[11] F. Kucukasik, O. Yenigun, and E. T. Oner, "Molasses as fermentation substrate for microbial biopolymer production," New Biotechnology, vol. 25, p. S250, 2009.

[12] A. L. Da Silva Berwanger, N. M. Domingues, L. T. Vanzo et al., "Production and rheological characterization of biopolymer of Sphingomonas capsulata ATCC 14666 using conventional and industrial media," Applied Biochemistry and Biotechnology, vol. 132, no. 1-3, pp. 942-950, 2006.

[13] Y. L. Mao, C. X. Tian, J. W. Zhu, T. Z. Zhang, and L. B. Tong, "Production of a novel biopolymer by culture of Bacillus cereus B-11 using molasses wastewater and its use for dye removal," in Frontiers of Manufacturing Science and Measuring Technology, R. Chen and W. L. Yao, Eds., vol. 230-232 of Advanced Materials Research, parts 1-3, pp. 1119-1122, Trans Tech Publications, Zurich, Switzerland, 2011.

[14] Y. O. Loginov, G. G. Khudaigulov, S. P. Chetverikov, A. I. Melent'ev, and O. N. Loginov, "Biopolymer of alginate nature with a predominance of L-guluronic acid," Applied Biochemistry and Microbiology, vol. 47, no. 3, pp. 311-314, 2011.

[15] G. Emtiazi, Z. Ethemadifar, and M. H. Habibi, "Production of extra-cellular polymer in Azotobacter and biosorption of metal by exopolymer," African Journal of Biotechnology, vol. 3, no. 6, pp. 330-333, 2004.

[16] T. M. Mata, A. C. Melo, M. Simões, and N. S. Caetano, "Parametric study of a brewery effluent treatment by microalgae Scenedesmus obliquus," Bioresource Technology, vol. 107, pp. 151$158,2012$.

[17] U. U. Nwodo, M. O. Agunbiade, E. Green, M. Nwamadi, K. Rumbold, and A. I. Okoh, "Characterization of an exopolymeric flocculant produced by a Brachybacterium sp.," Materials, vol. 6, no. 4, pp. 1237-1254, 2013.

[18] Y. L. Mao, X. C. Xiao, Y. J. Liu, E. L. Zhao, and L. B. Zhai, "Production of a novel biopolymer by culture of Pseudomonas fluorescens using brewery wastewater and its use for dye removal," in Advanced Materials Research, Z. H. Xu, G. Shen, and S. Lin, Eds., vol. 171-172, pp. 45-48, Trans Tech Publications, Zurich, Switzerland, 2011.

[19] I. K. Muniraj, L. W. Xiao, H. Liu, and X. M. Zhan, "Utilisation of potato processing wastewater for microbial lipids and $\gamma$-linolenic acid production by oleaginous fungi," Journal of the Science of Food and Agriculture, vol. 95, no. 15, pp. 3084-3090, 2015.

[20] G. G. Fonseca, G. G. Fonseca, J. de Arruda-Caulkins, and R. V. Antonio, "Production and characterization of poly-(3-hydroxybutyrate) from recombinant Escherichia coli grown on cheap renewable carbon substrates," Waste Management \& Research, vol. 26, no. 6, pp. 546-552, 2008.

[21] A. Daneshi, H. Younesi, S. M. Ghasempouri, and M. Sharifzadeh, "Production of poly-3-hydroxybutyrate by Cupriavidus necator from corn syrup: statistical modeling and optimization of biomass yield and volumetric productivity," Journal 
of Chemical Technology and Biotechnology, vol. 85, no. 11, pp. 1528-1539, 2010.

[22] P. I. Fernandes Jr., P. J. De Oliveira, N. G. Rumjanek, and G. R. Xavier, "Poly- $\beta$-hydroxybutyrate and exopolysaccharide biosynthesis by bacterial isolates from Pigeonpea [Cajanus cajan (L.) Millsp] root nodules," Applied Biochemistry and Biotechnology, vol. 163, no. 4, pp. 473-484, 2011.

[23] Y. González-García, M. A. Rosales, O. González-Reynoso, R. Sanjuán-Dueñas, and J. Córdova, "Polyhydroxybutyrate production by Saccharophagus degradans using raw starch as carbon source," Engineering in Life Sciences, vol. 11, no. 1, pp. 5964, 2011.

[24] G. S. Kiran, A. N. Lipton, S. Priyadharshini et al., "Antiadhesive activity of poly-hydroxy butyrate biopolymer from a marine Brevibacterium casei MSI04 against shrimp pathogenic vibrios," Microbial Cell Factories, vol. 13, article 114, 2014.

[25] S. K. Bhatia, N. Kumar, and R. K. Bhatia, "Stepwise bioprocess for exopolysaccharide production using potato starch as carbon source," 3 Biotech, vol. 5, no. 5, pp. 735-739, 2015.

[26] K. M. Nampoothiri, R. R. Singhania, C. Sabarinath, and A. Pandey, "Fermentative production of gellan using Sphingomonas paucimobilis," Process Biochemistry, vol. 38, no. 11, pp. 15131519, 2003.

[27] Neera, K. V. Ramana, and H. V. Batra, "Occurrence of celluloseproducing Gluconacetobacter spp. in fruit samples and kombucha tea, and production of the biopolymer," Applied Biochemistry and Biotechnology, vol. 176, no. 4, pp. 1162-1173, 2015.

[28] S. Deng, G. Yu, and Y. P. Ting, "Production of a bioflocculant by Aspergillus parasiticus and its application in dye removal," Colloids and Surfaces B: Biointerfaces, vol. 44, no. 4, pp. 179-186, 2005.

[29] A. Ely, M. Baudu, J.-P. Basly, and M. O. S. O. Kankou, "Copper and nitrophenol pollutants removal by Na-montmorillonite/alginate microcapsules," Journal of Hazardous Materials, vol. 171, no. 1-3, pp. 405-409, 2009.

[30] T. Y. Kim, H. J. Jin, S. S. Park, S. J. Kim, and S. Y. Cho, “Adsorption equilibrium of copper ion and phenol by powdered activated carbon, alginate bead and alginate-activated carbon bead," Journal of Industrial and Engineering Chemistry, vol. 14, no. 6, pp. 714-719, 2008.

[31] M. F. Elkady and H. S. Hassan, "Equilibrium and dynamic profiles of azo dye sorption onto innovative nano-zinc oxide biocomposite," Current Nanoscience, vol. 11, no. 6, pp. 805-814, 2015.

[32] Y. N. Mata, M. L. Blázquez, A. Ballester, F. González, and J. A. Muñoz, "Biosorption of cadmium, lead and copper with calcium alginate xerogels and immobilized Fucus vesiculosus," Journal of Hazardous Materials, vol. 163, no. 2-3, pp. 555-562, 2009.

[33] W. S. Tan and A. S. Y. Ting, "Alginate-immobilized bentonite clay: adsorption efficacy and reusability for $\mathrm{Cu}$ (II) removal from aqueous solution," Bioresource Technology, vol. 160, pp. 115-118, 2014.

[34] Y. H. Li, B. Xia, Q. S. Zhao et al., "Removal of copper ions from aqueous solution by calcium alginate immobilized kaolin," Journal of Environmental Sciences, vol. 23, no. 3, pp. 404-411, 2011.

[35] S. Kocaoba, Y. Orhan, and T. Akyüz, "Kinetics and equilibrium studies of heavy metal ions removalby use of natural zeolite," Desalination, vol. 214, no. 1-3, pp. 1-10, 2007.

[36] R. Petrus and J. K. Warchoł, "Heavy metal removal by clinoptilolite. An equilibrium study in multi-component systems," Water Research, vol. 39, no. 5, pp. 819-830, 2005.
[37] M. Sprynskyy, B. Buszewski, A. P. Terzyk, and J. Namieśnik, "Study of the selection mechanism of heavy metal $\left(\mathrm{Pb}^{2+}, \mathrm{Cu}^{2+}\right.$, $\mathrm{Ni}^{2+}$, and $\mathrm{Cd}^{2+}$ ) adsorption on clinoptilolite," Journal of Colloid and Interface Science, vol. 304, no. 1, pp. 21-28, 2006.

[38] H. Ertesvåg, S. Valla, and G. Skjåk-Bræk, Eds., Alginates: Biology and Applications, Springer, Berlin, Germany, 2009.

[39] G. L. Miller, "Use of dinitrosalicylic acid reagent for determination of reducing sugar," Analytical Chemistry, vol. 31, no. 3, pp. 426-428, 1959.

[40] H. Grasdalen, B. Larsen, and O. Smidsrød, "A p.m.r. study of the composition and sequence of uronate residues in alginates," Carbohydrate Research, vol. 68, no. 1, pp. 23-31, 1979.

[41] C. Peña, N. Campos, and E. Galindo, "Changes in alginate molecwlar mass distributions, broth viscosity and morphology of Azotobacter vinelandii cultured in shake flasks," Applied Microbiology and Biotechnology, vol. 48, no. 4, pp. 510-515, 1997.

[42] C. Peña, M. A. Trujillo-Roldán, and E. Galindo, "Influence of dissolved oxygen tension and agitation speed on alginate production and its molecular weight in cultures of Azotobacter vinelandii," Enzyme and Microbial Technology, vol. 27, no. 6, pp. 390-398, 2000.

[43] C. L. Krueger, C. M. Radetski, A. G. Bendia et al., "Bioconversion of cassava starch by-product into Bacillus and related bacteria polyhydroxyalkanoates," Electronic Journal of Biotechnology, vol. 15, no. 3, 2012.

[44] H. Ertesvåg, "Alginate-modifying enzymes: biological roles and biotechnological uses," Frontiers in Microbiology, vol. 6, article 523, 2015.

[45] J. H. Chen, H. Lin, Z. H. Luo, Y. S. He, and G. P. Li, “Cu(II)imprinted porous film adsorbent $\mathrm{Cu}-\mathrm{PVA}-\mathrm{SA}$ has high uptake capacity for removal of $\mathrm{Cu}(\mathrm{II})$ ions from aqueous solution," Desalination, vol. 277, no. 1-3, pp. 265-273, 2011.

[46] H. G. Park, T. W. Kim, M. Y. Chae, and I.-K. Yoo, "Activated carbon-containing alginate adsorbent for the simultaneous removal of heavy metals and toxic organics," Process Biochemistry, vol. 42, no. 10, pp. 1371-1377, 2007.

[47] W. M. Algothmi, N. M. Bandaru, Y. Yu, J. G. Shapter, and A. V. Ellis, "Alginate-graphene oxide hybrid gel beads: an efficient copper adsorbent material," Journal of Colloid and Interface Science, vol. 397, pp. 32-38, 2013.

[48] B. An, H. Son, J. Chung, J. W. Choi, S. H. Lee, and S. W. Hong, "Calcium and hydrogen effects during sorption of copper onto an alginate-based ion exchanger: batch and fixed-bed column studies," Chemical Engineering Journal, vol. 232, pp. 51-58, 2013.

[49] Y. H. Li, F. Q. Liu, B. Xia et al., "Removal of copper from aqueous solution by carbon nanotube/calcium alginate composites," Journal of Hazardous Materials, vol. 177, no. 1-3, pp. 876-880, 2010.

[50] S. F. Lim and J. P. Chen, "Synthesis of an innovative calciumalginate magnetic sorbent for removal of multiple contaminants," Applied Surface Science, vol. 253, no. 13, pp. 5772-5775, 2007.

[51] Y. F. Wang, M. Luo, F. Xu, and W. Z. Zhang, "Conversion of volcanic tephra to zeolites for calcium ion cross-linked alginatezeolite composites for enhanced aqueous removal of $\mathrm{Cu}$ (II) ions," Water, Air, \& Soil Pollution, vol. 226, no. 9, article 286, 2015. 

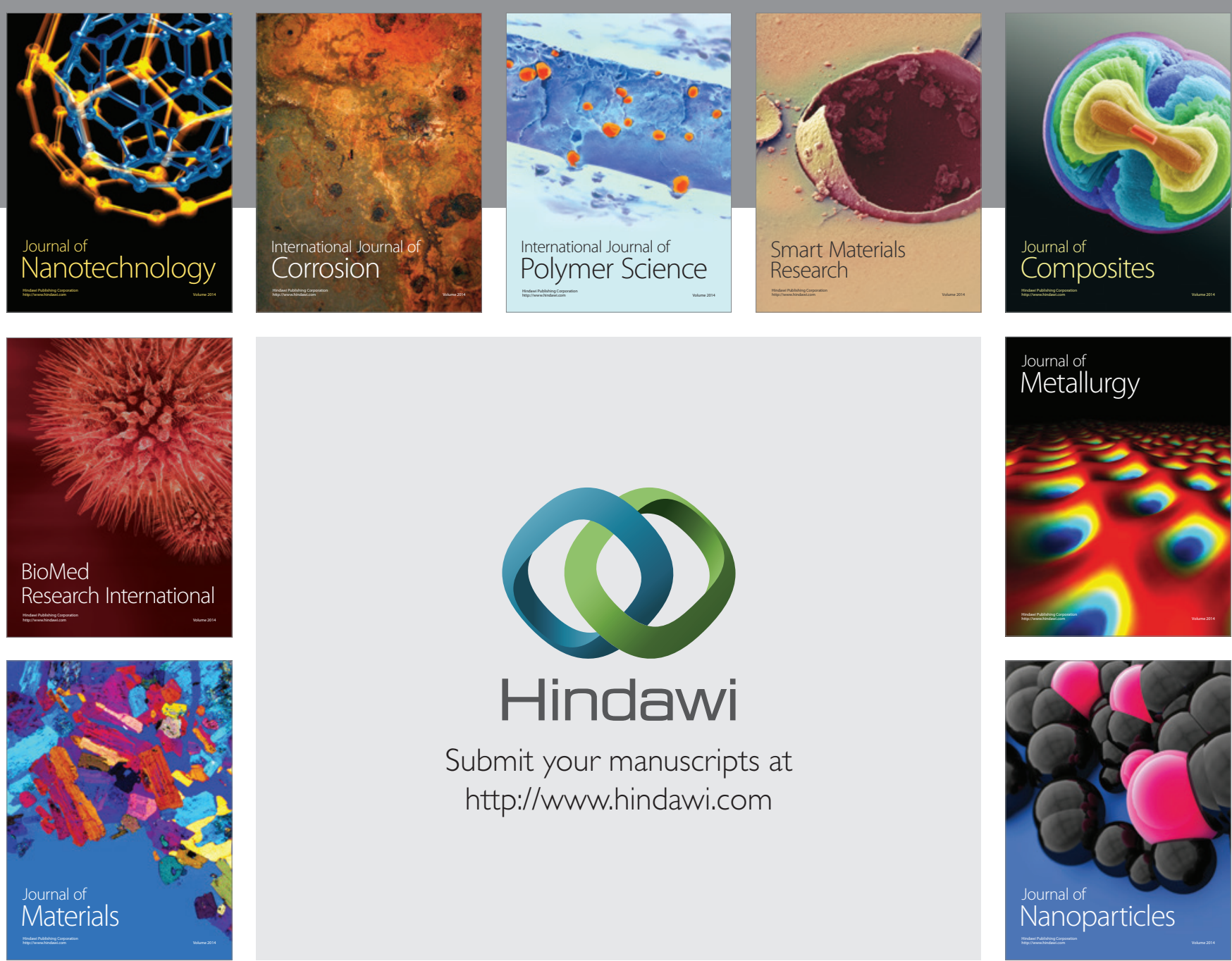

\section{Hindawi}

Submit your manuscripts at

http://www.hindawi.com

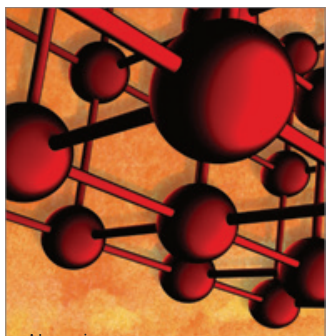

Materials Science and Engineering
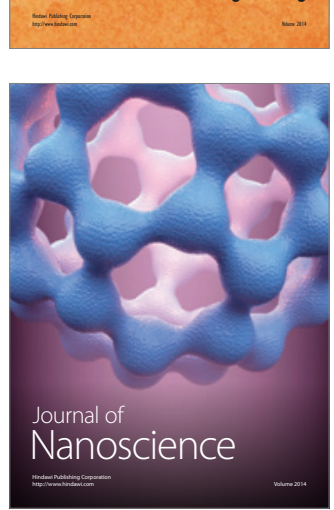
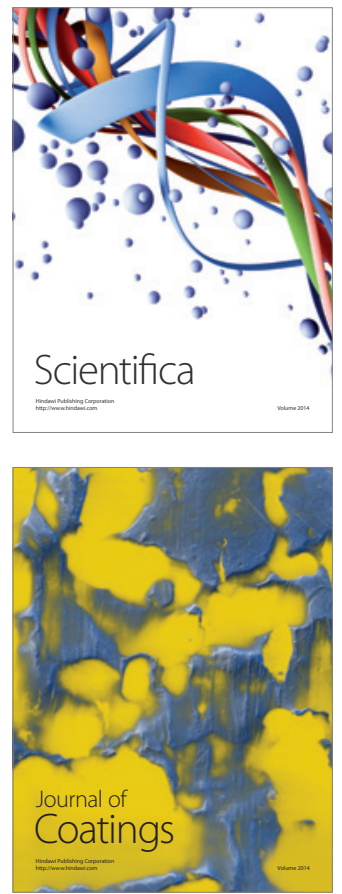
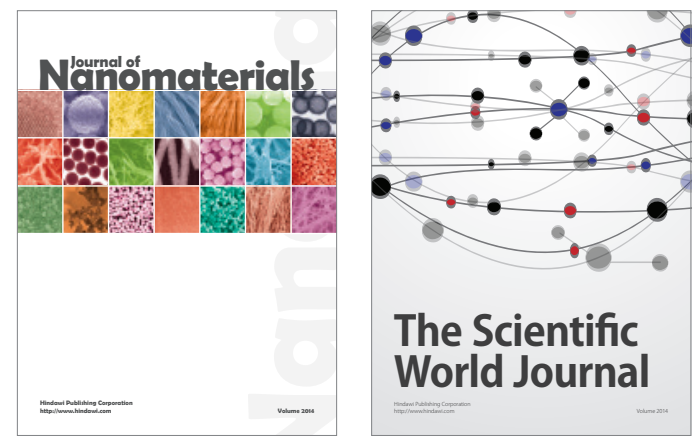

The Scientific World Journal
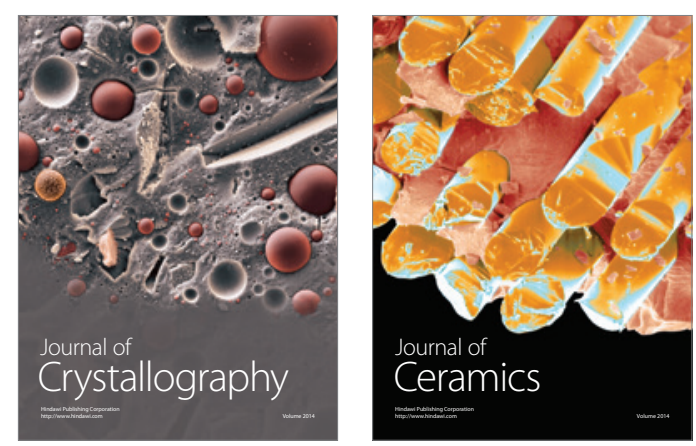
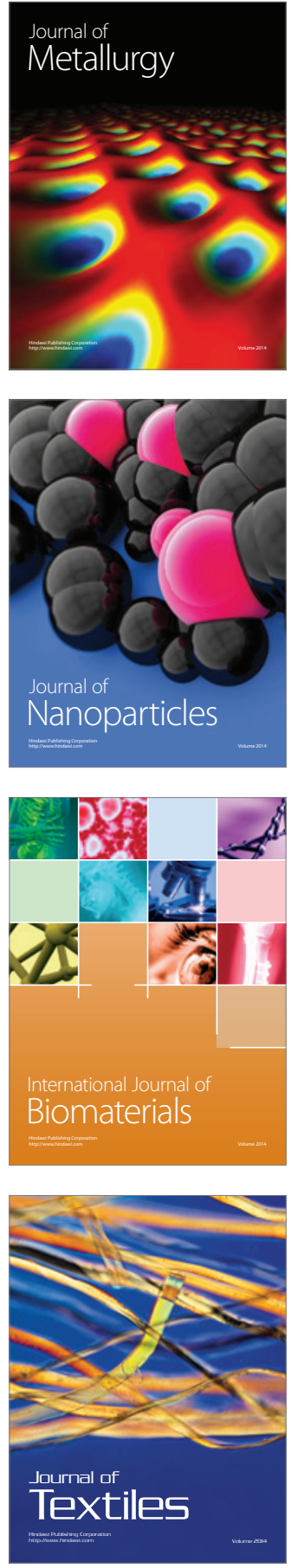